\title{
PENGARUH GAYA KEPEMIMPINAN \\ TERHADAP KINERJA PEGAWAI PADA \\ KANTOR SEKRETARIAT DPRD KABUPATEN MAMASA
}

\author{
Indra Wilyanti' ${ }^{1}$ Aco Dahrul Saharuddin², Sri Yuyun ${ }^{3}$ \\ ${ }^{1}$ Prodi Ilmu Pemerintahan, Fakultas Ilmu Sosial dan Ilmu Pemerintahan \\ Universitas Al Asyariah Mandar \\ Email: solatatomamasa@gmail.com \\ 1Prodi Ilmu Pemerintahan, Fakultas Ilmu Sosial dan Ilmu Pemerintahan \\ Universitas Al Asyariah Mandar \\ Email: acodahrulsaharuddin@gmail.com \\ 1Prodi Ilmu Komunikasi, Fakultas Ilmu Sosial dan Ilmu Pemerintahan \\ Universitas Al Asyariah Mandar \\ Email: yuyunsri765@gmail.com
}

\begin{abstract}
The purpose of this study was to determine the effect of leadership style on employee performance at the Mamasa Regency DPRD secretariat office and employee performance at the Mamasa Regency DPRD secretariat office. The type of research that the author uses in this research is empirical research. which departs from empirical data that ends with the discovery. Empirical research is intended as an effort to approach the problem under study with a legal nature that is in accordance with the reality faced in society. The results of the study indicate that the workplace, compensation, and leadership attitudes are factors that together have a significant effect on the work motivation of the Mamasa Regency DPRD Secretariat employees and provide an indication that the most dominant work motivation affecting the Mamasa Regency DPRD Secretariat employees is the workplace factor.
\end{abstract}

\begin{abstract}
ABSTRAK
Tujuan penelitian ini adalah untuk mengetahui pengaruh gaya kepemimpinan terhadap kinerja pegawai pada kantor sekretariat DPRD Kabupaten Mamasa. Jenis penelitian yang penulis gunakan dalam penelitian ini adalah penelitian empiris. yang berangkat dari data empiris yang diakhiri dengan penemuan. Penelitian empiris dimaksudkan sebagai upaya untuk mendekati masalah yang diteliti dengan sifat hukum yang sesuai dengan kenyataan yang dihadapi dalam masyarakat. Hasil penelitian menunjukkan bahwa tempat kerja, kompensasi, dan sikap kepemimpinan merupakan faktor yang secara bersama-sama berpengaruh signifikan terhadap motivasi kerja
\end{abstract}


pegawai Sekretariat DPRD Kabupaten Mamasa dan memberikan petunjuk bahwa motivasi kerja paling dominan berpengaruh terhadap pegawai Sekretariat DPRD Kabupaten Mamasa adalah faktor tempat kerja.

\section{Kata Kunci: Gaya Kepemimpinan, Kinerja Pegawai, Sekretariat DPRD.}

\section{PENDAHULUAN}

Mangkunegara (2000) menyebutkan, faktor yang mempengaruhi kinerja adalah kemampuan (ability) dan faktor motivasi. Setiap organisasi maupun perusahaan akan berusaha untuk meningkatkan kinerja karyawan untuk mencapai tujuan organisasi yang telah ditetapkan. Berbagai cara ditempuh untuk meningkatkan kinerja karyawan misalnya melalui pendidikan dan pelatihan, pemberian kompensasi dan motivasi serta menciptakan lingkungan kerja yang baik

Salah satu faktor yang dapat digunakan untuk meningkatkan kinerja karyawan adalah Gaya kepemimpinan, komunikasi organisasi dan motivasi kerja (Putu Sunarcaya, 2008).

Motivasi menjadi pendorong seseorang melaksanakan suatu kegiatan guna mendapat hasil yang terbaik. Oleh karena itulah tidak heran jika karyawan yang mempunyai motivasi kerja yang tinggi biasanya mempunyai kinerja yang tinggi pula. Untuk itu motivasi kerja karyawan perlu dibangkitkan agar karyawan dapat menghasilkan kinerja yang terbaik

Menurut Mangkunegara (2012:68) dalam bukunya Manajemen Sumber Daya Manusia Perusahaan, kinerja yaitu sebagai hasil kerja secara kualitas dan kuantitas yang dicapai oleh seorang pegawai dalam melaksanakan tugasnya sesuai dengan tanggung jawab yang diberikannya. Kinerja merupakan perilaku nyata yang ditampilkan setiap orang sebagai prestasi kerja yang dihasilkan oleh pegawai sesuai dengan perannya dalam perusahaan.

Sekertariat Dewan Perwakilan Rakyat Daerah (DPRD) Kabupaten Mamasa adalah satu satu instansi pemerintahan yang dipimpin oleh seorang Kepala Kantor dan dibantu oleh tiga (3) Kepala bagian dan Sembilan Kepala SubBagian, Setiap Kantor Sekertariat Dewan Perwakilan Rakyat Daerah di Indonesia telah diberikan atau dibebankan tugas dan targetnya masing-masing. Dan setiap Kepala Kantor dapat melakukan kebijakan-kebijakan yang berbeda-beda dalam usaha pencapaian kesuksesan. Kebijakan ini sendiri pasti akan membentuk tipe kepemimpinan yang berbeda-beda, mengingat pentingnya peran Sekertariat DPRD dalam proses pembuatan serta 
pengawasan terhadap pelaksanaan Peraturan Daerah, dinilai belum maksimal dan perlu ditingkatkan. 


\section{METODE PENELITIAN}

Jenis Penelitian yang penulis pergunakan dala mpenelitian ini adalah jenis penelitian hukum sosiologis/empiris. Penelitian empiris adalah penelitian yang bertolakdari data empirik yang berakhir dengan penemuan.(Middle-range theory maupun grandtheory); dimana kebenaran ditentukan, reabilitas dan validitas data dikumpulkan, diklasifikasikan, dan diinterprestasikan. Penelitian Empiris dimasudkan sebagai usaha mendekati masalah yang diteliti dengan sifat hukum yang sesuai dengan kenyataan yang dihadapi dalam masyarakat (Hadikusuma, 1995).

\section{HASIL PENELITIAN}

\section{Hasil Pengukuran Responden}

Melalui penelusuran berupa data sekunder dari hasil penelitian faktorfaktor yang berpengaruh terhadap kinerja berupa variabel bebas : $\mathrm{X} 1, \mathrm{X} 2, \mathrm{X} 3$, dan X4 (tempat kerja, kompensasi, sikap pimpinan, dan penghargaan, maka dapat disajikan sebagai berikut :

\section{Tempat Kerja}

Hasil pengukuran variabel Tempat Kerja, menunjukkan bahwa dari 34 responden, konsentrasi penilaian ada pada kategori memuaskan sebanyak 19 responden $(55,88 \%)$, selanjutnya 5 responden $(14,71 \%)$ memilih kategori cukup memuaskan dan 10 responden $(29,41 \%)$ memilih tidak memuaskan. Lihat tabel 11.

Tabel 11;

Distribusi Frekuensi Tempat Kerja

\begin{tabular}{|c|l|c|c|}
\hline \multirow{2}{*}{ No } & \multicolumn{2}{|c|}{ Tempat Kerja } & \multicolumn{2}{|c|}{ Frekuensi } \\
\cline { 3 - 4 } & & Mutlak & Relatif (\%) \\
\hline 1. & Sangat Memuaskan & - & - \\
2. & Memuaskan & 19 & 55,88 \\
3. & Cukup Memuaskan & 5 & 14,71 \\
4. & Tidak Memuaskan & 10 & 29,41 \\
5. & SangatTidak Memuaskan & - & - \\
\hline \multicolumn{2}{|c|}{ Jumlah } & 34 & 100 \\
\hline
\end{tabular}

Sumber: Data sekunder diolah, 2019

Dari tabel tersebut menggambarkan kecenderungan responden mengatakan bahwa tempat kerja dirasakan masih pada taraf tidak memuaskan dan masih perlu untuk ditingkatkan. 


\section{Kompensasi}

Hasil pengukuran variabel kompensasi, menunjukkan bahwa dari 34 responden, konsentrasi penilaian ada pada kategori memuaskan sebanyak 20 responden $(58,82 \%)$, selanjutny 10 responden $(29,41 \%)$ memilih kategori cukup memuaskan dan selebihnya 4 responden (11,76\%) memilih kategori tidak memuaskan. Lihat tabel 12.

Tabel 12;

Distribusi Frekuensi Kompensasi

\begin{tabular}{|c|c|c|c|}
\hline \multirow{2}{*}{ No } & \multirow{2}{*}{ Kompensasi } & \multicolumn{2}{|c|}{ Frekuensi } \\
\hline & & Mutlak & Relatif (\%) \\
\hline 1. & Sangat Memuaskan & - & - \\
\hline 2. & Memuaskan & 20 & 58,82 \\
\hline 3. & Cukup Memuaskan & 10 & 29,41 \\
\hline 4. & Tidak Memuaskan & 4 & 11,76 \\
\hline 5. & $\begin{array}{ll}\text { Sangat } & \text { Tidak } \\
\text { Memuaskan } & \\
\end{array}$ & - & - \\
\hline \multicolumn{2}{|c|}{ Jumlah } & 34 & 100 \\
\hline
\end{tabular}

Sumber : Data sekunder diolah, 2016

\section{Sikap Pimpinan}

Hasil pengukuran variabel sikap pimpinan, menunjukkan bahwa dari 34 responden, konsentrasi penilaian ada pada kategori memuaskan sebanyak 20 responden $(58,82 \%)$, selanjutnya 10 responden $(29,41 \%)$ memilih kategori cukup memuaskan dan selebihnya 4 responden (11,76\%) memilih kategori tidak memuaskan. Lihat tabel 13.

\section{Tabel 13;}

Distribusi Frekuensi Sikap Pimpinan (X3)

\begin{tabular}{|c|l|c|c|}
\hline \multirow{2}{*}{ No } & \multicolumn{2}{|c|}{ Sikap Pimpinan } & \multicolumn{2}{|c|}{ Frekuensi } \\
\cline { 3 - 4 } & & Mutlak & Relatif (\%) \\
\hline 1. & Sangat Memuaskan & - & - \\
2. & Memuaskan & 20 & 58,82 \\
3. & Cukup Memuaskan & 10 & 29,41 \\
4. & Tidak Memuaskan & 4 & 11,76 \\
5. & Sangat Tidak Memuaskan & - & - \\
\hline \multicolumn{2}{|c|}{ Jumlah } & 34 & 100 \\
\hline
\end{tabular}

Sumber : Data sekunder diolah, 2016

\section{Penghargaan}

Hasil pengukuran variabel Penghargaan, menunjukkan bahwa dari 34 responden, konsentrasi penilaian ada pada kategori memuaskan sebanyak 20 responden $(58,82 \%)$, selanjutnya 10 responden $(29,41 \%)$ memilih kategori cukup memuaskan dan selebihnya 4 responden $(11,76 \%)$ memilih kategori tidak memuaskan. Lihat tabel 14. 
Tabel 14;

Distribusi Frekuensi Penghargaan

\begin{tabular}{|c|l|c|c|}
\hline \multirow{2}{*}{ No } & \multicolumn{1}{|c|}{ Penghargaan } & \multicolumn{2}{|c|}{ Frekuensi } \\
\cline { 3 - 4 } & & Mutlak & Relatif (\%) \\
\hline 1. & Sangat Memuaskan & - & - \\
2. & Memuaskan & 20 & 58,82 \\
3. & Cukup Memuaskan & 10 & 29,41 \\
4. & Tidak Memuaskan & 4 & 11,76 \\
5. & Sangat Tidak Memuaskan & - & - \\
\hline \multicolumn{2}{|c|}{ Jumlah } & 34 & 100 \\
\hline
\end{tabular}

Sumber : Data sekunder diolah, 2019

\section{Analisis Data}

Dari seluruh populasi berjumlah 34 orang secara keseluruhan dijadikan responden obyek penelitian di Kantor Sekertariat DPRD diperoleh data yang merupakan hasil penelitian untuk dianalisis dengan menggunakan metode Deskriftif Kuantitatif.

Model regresi linear berganda digunakan sebagai analisis kuantitatif pada variabel-variabel independen (tempat kerja, kompensasi, sikap pimpinan, penghargaan dan usia) terhadap variabel dependen Y (kinerja), untuk mengetahui faktor-faktor yang berpengaruh terhadap tingkat kinerja.

Dengan analisis regresi linear berganda nantinya akan diketahui apakah variabel-variabel independen baik secara individu (partial) atau secara simultan (keseluruhan/bersama-sama) berpengaruh terhadap variabel dependen yang dalam hal ini adalah kinerja.

Untuk menguji apakah variabel X1, X2, X3, X4, X5 (tempat kerja, kompensasi, sikap pimpinan, penghargaan dan usia) secara bersama-sama berpegaruh terhadap Y (Kinerja) secara signifikan, maka akan dilihat seberapa besar nilai $\mathrm{F}$ dan $\mathrm{p}$ (probabilitas). Apabila $\mathrm{p}<\alpha=0,05$ maka pengaruhnya signifikan dan bila sebaliknya $\mathrm{p}>\alpha=0,05$ maka pengaruhnya tidak signifikan.

Untuk membuat kesimpulan mengenai pengaruh masing-masing variabel independen $(\mathrm{X})$ terhadap Variabel dependen (Y) maka harus diambil dari dua keputusan; membandingkan statistik hitung dengan tabel dan nilai probabilitas seperti berikut:

Hipotesis:

$H o=$ Model dan Koefisien regresi tidak signifikan; variabel bebas tidak berpengaruh secara sinifikan terhadap variabel terikat (kinerja pegawai dinas Perindustrian \&Pariwisata Kabupaten Bulukumba).

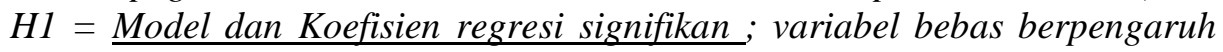
secara signifikan terhadap variabel terikat (kinerja pegawai dinas Perindustrian \&Pariwisata Kabupaten Bulukumba). 
Pengambilan Keputusan akan diambil dengan melihat:

1) Dengan membandingkan Statistik hitung dengan Statistik Tabel. Jika t hitung $<\mathrm{t}$ tabel, maka $\mathrm{H}_{0}$ diterima dan $\mathrm{H}_{1}$ ditolak. Jika t hitung $>\mathrm{t}$ tabel, maka $\mathrm{H}_{0}$ ditolak dan $\mathrm{H}_{1}$ diterima. Nilai t tabel $(\mathrm{df}=\mathrm{dk})$

2) Berdasarkan Probabilitas Apabila prababilitas $>\alpha=0,05$, maka $\mathrm{H}_{0}$ diterima dan $\mathrm{H}_{1}$ ditolak. Apabila probabilitas $<\alpha=0,05$, maka $\mathrm{H}_{0}$ ditolak dan $\mathrm{H}_{1}$ diterima.

Dengan memperhatikan parameter-parameter pada hasil olahan data menggunakan komputer dengan program SPSS. 10, seperti pada lampiran 1 maka dapat dijelaskan analisisnya sebagai berikut :

\section{Bagian Descriptive Statistics}

Dilihat pada out put halaman 1.

a. Rata-rata kinerja (Y) pegawai dengan jumlah pegawai 34 orang, adalah 2,9376 (tidak memuaskan) dengan standar deviasi 0,6836

b. Rata-rata penilaian tempat kerja $\left(X_{1}\right)$ pegawai dengan jumlah pegawai 34 orang adalah 7,5625 (tidak memuaskan) dengan standar deviasi 0,6875

c. Rata-rata penilaian kompensasi $\left(\mathrm{X}_{2}\right)$ pegawai dengan jumlah pegawai 34 orang, adalah 2,7833 (tidak memuaskan) dengan standar deviasi 0,6783.

d. Rata-rata penilaian sikap pimpinan $\left(\mathrm{X}_{3}\right)$ terhadap pegawai dengan jumlah pegawai 34 orang, adalah 3,2444 (tidak memuaskan) dengan standar deviasi 0,4282 .

e. Rata-rata penilaian penghargaan $\left(\mathrm{X}_{4}\right)$ terhadap pegawai dengan jumlah pegawai 34 orang, adalah 1,6333 (tidak memuaskan) dengan standar deviasi 0,8503 .

f. Rata-rata usia $\left(\mathrm{X}_{5}\right)$ pegawai dengan jumlah pegawai 34 orang, adalah 3,0333 (tidak memuaskan) dengan standar deviasi 1,0662.

2. Bagian Korelasi

Bila diurutkan, besar hubungan antar variabel terikat dengan kelima variabel bebas secara individual, adalah :

i. $\quad$ Variabel tempat kerja $=0,917$

ii. Variabel sikap pimpinan $=0,857$

iii. Variabel penghargaan $=0,744$

iv. Variabel kompensasi $=0,723$ dan

v. Variabel usia $=0,201$

Hal ini menunjukkan bahwa variabel usia mempunyai korelasi yang lemah (di bawah 0,5) terhadap kinerja. 
Terjadi multikolinieritas atau interkorelasi antara keempat variabel bebas, selain variabel usia. Ini bisa dilihat angka korelasi yang kuat antara keempat peubah tadi (di atas 0,8$)$.

Tingkat signifikan koefisien korelasi individual dari keempat variabel (tempat kerja, kompensasi, sikap pimpinan dan penghargaan) sama bila diukur dari probabilitas. Sedangkan variabel usia tidak berkorelasi secara signifikan $(\mathrm{p}>0,05)$.

3. Bagian Variabel Entered/Removed

Pada bagian ini diperlihatkan bahwa setelah dalam model pertama semua variabel bebas dimasukkan, maka selanjutnya analisis dilakukan secara otomatis untuk mengeluarkan variabel yang kurang layak untuk masuk dalam regresi sistem ini. Sehingga model kedua memperlihatkan variabel penghargaan $\left(\mathrm{X}_{4}\right)$ dikeluarkan. Selanjutnya model ketiga mengeluarkan kembali variabel usia $\left(\mathrm{X}_{5}\right)$ dari regresi.

Sehingga akhirnya setelah melewati tiga tahapan, variabel bebas yang layak dipertahankan untu dimasukkan dalammodel regresi adalah variabel; tempat kerja $\left(\mathrm{X}_{1}\right)$, kompensasi $\left(\mathrm{X}_{2}\right)$ dan sikap pimpinan $\left(\mathrm{X}_{3}\right)$.

4. Bagian Model Summary

Pada bagian ini melanjutkan pada bagian sebelumnya bahwa, dengan hanya tiga variabel bebas (tempat kerja, kompensasi dan sikap pimpinan) sudah dapat mendapatkan hubungan yang sama ketika menggunakan lima variabel bebas. Terpautnya hanya seperseribu, lihat adjusted $R$ square $(0,879$ menjadi 0,878) ini sangat kecil bedanya, namun lebih efisien hanya dengan tiga variabel masukan.

Dari hal tersebut juga dapat diambil analisis bahwa $87,8 \%$ kinerja pegawai dapat dijelaskan oleh variabel tempat kerja, kompensasi dan sikap pimpinan, sedangkan selebihnya $(12,2 \%)$ dijelaskan oleh sebab lain.

5. Bagian Anova

Dari uji anova atau $\mathrm{F}$ test, didapatkan $\mathrm{F}$ hitung dengan model regresi yang terbaru sebesar 70,328 dengan tingkat signifikan 0,000 jauh lebih kecil dari $\alpha=0,05$ maka model regresi dapat dipakai untuk memprediksi kinerja. Atau dapat dikatakan; tempat kerja, kompensasi dan sikap pimpinan secara bersama-sama berpengaruh terhadap kinerja.

6. Bagian Coefficients

Dari output ini bisa didapatkan persamaan regresi dari model pertama (1) sebelum dikeluarkannya variabel penghargaan $\left(\mathrm{X}_{4}\right)$ dan usia $\left(\mathrm{X}_{5}\right)$ sebagai berikut : 
$Y=-3,688+1,948 X_{1}-0,302 X_{2}+0,480 X_{3}-0,073 X_{4}+0,047 X_{5}$

Namun setelah dikeluarkannya kedua variabel di atas karena dari uji signifikan ternyata kedua variabel tersebut baik dari uji $\mathrm{t}$ maupun probabilitas tidak signifikan (lihat kolom t dan Sig). Maka sekarang yang dianggap sebagai persamaan regresi terbaik/layak, adalah :

$$
\begin{aligned}
Y=-3,173+1,802 X_{1}-0,287 X_{2}+0,464 X_{3} \\
\text { Dimana: } Y=\text { Kinerja } \\
\\
X_{1}=\text { Tempat Kerja } \\
\\
X 2=\text { Kompensasi } \\
\\
X 3=\text { Sikap Pimpinan }
\end{aligned}
$$

Persamaan tersebut berarti :

a. Setiap peningkatan satu-satuan tempat kerja, akan menambah 1,802 satusatuan kinerja pegawai.

b. Setiap peningkatan satu-satuan kompensasi, akan mengurangi 0,287 satusatuan kinerja pegawai.

c. Setiap peningkatan satu-satuan sikap pimpinan, akan menambah 0,464 satu-satuan kinerja pegawai.

d. Dari ketiga variabel bebas tersebut ada dua yang berkorelasi positif dan satu variabel berkorelasi negatif.

Selanjutnya untuk menguji signifikan konstanta dan variabel bebas digunakan uji t dan probabilitas.

Dari nilai probabilitas model regresi yang layak baik secara individual maupun secara bersama nilainya di bawah $\alpha=0,05$, jadi dari segi ini model signifikan.

Untuk uji t, dengan $\mathrm{df}=29-3=26$ dari $\mathrm{t}$ tabel didapat 2,06 sedangkan nilai $\mathrm{t}$ hitung model baik secara bersama-sama maupun individual mendapatkan nilai yang lebih tinggi $(\mathrm{t} 1=5,764, \mathrm{t} 2=2,367$ dan $\mathrm{t} 3=2,649)$ dari $\mathrm{t}$ tabel $(\mathrm{t}$ hit $>\mathrm{t}$ tabel). Dari segi inipun model signifikan.

Probabilitas $<0,05$, maka $\mathrm{H}_{0}$ ditolak dan $\mathrm{H}_{1}$ diterima,

$\mathrm{t}$ hitung $>\mathrm{t}$ tabel, maka $\mathrm{H}_{0}$ ditolak dan $\mathrm{H}_{1}$ diterima,

Dari hal tersebut maka dapat diambil maknanya bahwa; tempat kerja, kompensasi dan sikap pimpinan secara bersama-sama berpengaruh secara signifikan terhadap kinerja pegawai.

7. Bagian Collinearity Diagnostics

Model regresi yang baik seharusnya tidak terjadi korelasi di antara sesama variabel bebas, atau biasa dikatakan tidak terjadi interkorelasi antar variabel bebas. 
Pada bagian ini sudah kelihatan pada kolom Eigenvalue, bahwa model ketiga semua variabel bebas mendekati nol, ini mengindikasikan bahwa terjadi interkorelasi sesama variabel. Ebih diperkuat lagi pada kolom Condition Indeks yang nilainya melebihi 15 bahkan ada yang lebih dari 30, ini berarti dugaan terjadinya problem interkorelasi semakin jelas.

Untuk mengatasi persoalan tersebut pada penulisan skripsi ini tidak penulis bahas. Persoalaan yang timbul adalah keterbatasan kemampuan penulis saat ini. Itu semua bisa diselesaikan menggunakan buku statistik lanjutan.

8. Bagian Exeluded Variables

Pada bagian ini menjelaskan bagaimana tentang sebab variabel yang tidak layak dimasukkan pada model regresi pada bagian depan. Disitu diperhatikan bahwa kedua variabel bebas yakni ; penghargaan dan usia baik nilai signifikansinya (probabilitasnya) semua lebih besar dari 0,005 sedangkan nilai t hitungnya keduanya lebih kecil dari t tabel. Untuk itulah mereka layak untuk dikeluarkan dari model regresi yang ada.

9. Bagian Charts

Pada bagian ini digambarkan grafik hubungan masing-masing ketiga variabel bebas secara individu terhadap variabel terikat (diagram titik).

Variabel tempat kerja dan variabel sikap pimpinan $\left(\mathrm{X}_{1}, \mathrm{X}_{3}\right)$ berkorelasi positif terhadap kinerja, berarti grafik lurusnya naik dari kiri bawah menuju kanan atas. Sedangkan variabel kompensasi $\left(\mathrm{X}_{2}\right)$ berkorelasi negatif terhadap kinerja, maka grafik menurun dari kiri atas menuju kanan bawah.

\section{Pembahasan Hasil Penelitan}

\section{Faktor- Faktor Yang Mempengaruhi Kinerja}

Berdasarkan hasil analisis data, mengambarkan data memberi petunjuk pada awalnya bahwa secara bersama-sama lima faktor (variabel bebas), yakni : tempat kerja, kompensasi, sikap pimpinan, penghargaan dan usia berpengaruh nyata terhadap kinerja pegawai.

Akan tetapi setelah melalui tahap penyeleksian pengeluaran variabel bebas yang secara individu tidak signifikan pengaruhnya terhadap kinerja, ternyata variabel penghargaan dan variabel usia tidak akan keluar dari model regresi yang layak.

Akhirnya tinggal tiga faktor (variabel bebas); tempat kerja, kompensasi dan sikap pimpinan yang berpengaruh nyata terhadap kinerja (variabel terikat) pegawai Kantor Sekertariat DPRD. Kecenderungan rata-rata responden tidak merasakan tingkat kinerja pada level tidak memuaskan,

Hasil analisis tersebut mengandung arti bahwa dalam rangka mningkatkan kinerja pegawai di Kantor Sekertariat DPRD dan untuk lebih memberdayakan 
SDM yang ada dalam rangka peningkatan prestasi kerja pegawai, maka lima faktor tersebut merupakan satu kesatuan yang harus secara serius diperhatikan oleh pihak pmpinan/manajemen.

Akan tetapi perlu juga diperhatikan faktor-faktor lainnya yang dapat berpengaruh terhadap kinerja pegawai karena masih kurang lebih 12,00\% belum sempat diteliti. Faktor-faktor itu misalnya beban keluarga, promosi, minat dan bakat, status pekerjaan, jauhnya tempat tinggal, pendapatan tambahan di luar kantor dan yang lainnya.

Secara individual pengaruh dari masing-masing variabel bebas terhadap variabel terikat dapat dijelaskan sebagai berikut:

\section{a. Tempat Kerja}

Pengaruh nyata ditunjukkan oleh variabel tempat kerja terhadap kinerja pegawai. Hal ini bisa dikaji dari beberapa aspek yang menunjang suasana kerja di Kantor Sekertariat DPRD . Masalah keamanan sangat kondusif, contoh pencurian yang kecilpun hampir tidak pernah terjadi, dilain sisi resiko kecelakaan kerja pada pegawai juga sangat kecil karena tidak ada alat/barang yang dihadapi saat kerja bisa membahayakan secara fatal. Namun ketenangan dalam bekerja terutama ketenangan karena suara cukup mengganggu karena Sekolah dan minimnya fasilitas kantor yang ada. Demikian juga tingkat konflik antar pegawai cukup rendah ini bisa dilihat dari hasil pengambilan data yang menunjukkan hanya beberapa responden yang merasakan cukup sering terjadi konflik, dan selebihnya merasakan kadang-kadang bahkan tidak pernah berkonflik.

Sarana dan prasarana adalah penunjang penting kelancaran pekerjaan pegawai. Bila hal tersebut memadai akan sangat menunjang pelaksanaan tugas, namun bila sebaliknya maka kelancaran pelaksanaan tugas pun akan terhambat. Aula tempat pertemuan belum memadai dan luasnya lahan yang membutuhkan perawatan sementara tukang kebun tidak ada.

Dalam hal ini sebenarnya responden rata-rata merasakan bahwa nilai tempat kerja adalah baru taraf cukup memuaskan, nilai Mean $=3,2714$. Sehingga masih perlu usaha untuk ditingkatkan dari masing-masing sub komponen tempat kerja yang menunjang.

\section{b. Kompensasi}

Pengaruh variabel kompensasi signifikan/nyata dan berkorelasi negatif terhadap kinerja pegawai Kantor Sekertariat DPRD Ternyata kompensasi yang diterima oleh pegawai setiap bulan belum memberikan suatu kepuasan yang berarti, bahkan semakin banyak kompensasi yang diterima berkecenderungan semakin kurang puas. Ini dikarenakan kompensasi yang diterima relatif kecil bila dibandingkan dengan selain PNS. Rata-rata yang memperoleh kompensasi lebih banyak adalah yang memegang jabatan. Biasanya gaya hidup dan prestise karena memegang jabatan menjadikan pengeluaran semakin banyak, juga dengan beban 
kehidupan keseharian semakin mempunyai jabatan biasanya usia sudah senior sehingga anak semakin banyak dan tumbuh yang semuanya akan berdampak pada pengeluaran. Kenaikan gajipun akan berjalan lambat dan akan selalu ketinggalan dengan laju inflasi, keadaan ini akan menimbulkan kepasrahan dan ketidakpastian.

c. Sikap Pimpinan

Sikap pimpinan berkorelasi Negatif,tidak signifikan, terhadap kinerja pegawai Kantor Sekertariat DPRD . Hal tersebut (pimpinan) adalah merupakan kebutuhan yang penting dalam setiap organisasi. Maju mundurnya suatu organisasi akan sangat ditunjang bagaimana sikap pimpinan terhadap bawahannya. Pimpinan yang memanusiakan bawahannya serta tidak menganggap mereka adalah mesin, namun karyawan adalah mitra kerja dan merupakan bagian yang sangat penting dalam memajukan perusahaan/organisasi.

Akan tetapi pada penelitian data yang didapatkan sikap pimpinan masih dirasakan baru taraf cukup memuaskan sebagaimana rata-rata yang diperoleh dari reponden. Memang peneliti selaku karyawan masih melihat celah-celah yang perlu ditingkatkan antara lain; sangat minimnya rapat-rapat yang dipimpin langsung oleh pimpinan, sehingga bimbingan dirasakan sangat kurang termasuk hubungan/kontak dengan personil dirasakan masih kurang. Tidak memberikan pembagian tugas yang jelas pada bawahannya sehingga ada kalanya terjadi ketidaktahuan bawahan apa yang seharusnya diprbuat bahkan sering terjadi tumpang tindih pekerjaan siapa yang seharusnya mengerjakan.

\section{Faktor Yang Paling Dominan Mempengaruhi Kinerja}

Dari ketiga variabel bebas di atas, yang paling dominan pengaruhnya (dilihat besarnya koefisien regresi), maka tempat kerjalah yang paling dominan dengan besar koefisien regresi $(\mathrm{B})=1,802$.

Di sisi lain walaupun variabel-variabel bebas tersebut signifikan secara statistik namun masih terdapat problem interkorelasi sesama variabel bebas. Hal ini menjadi perhatian tersendiri nantinya bagi peneliti berikutnya agar bisa mengatasinya.

\section{KESIMPULAN}

Dari uraian pembahasan di atas sesuai dengan hasil penelitian, dapat disimpulkan bahwa tempat kerja, kompensasi, dan sikap pimpinan merupakan faktor-faktor yang secara bersama-sama berpengaruh secara signifikan terhadap motivasi kerja pegawai Kantor Sekretariat DPRD Kabupaten Mamasa. Pada hasil penelitian ini memberi petunjuk bahwa yang paling dominan berpengaruh secara signifikan terhadap motivasi kerja pegawai Kantor Sekretariat DPRD Kabupaten Mamasa adalah faktor tempat kerja Kantor Sekretariat DPRD Kabupaten Mamasa 


\section{SARAN}

Berdasarkan kesimpulan yang telah dikemukakan, maka dapat disarankan beberapa hal. Pertama; agar faktor tempat kerja, kompensasi dan sikap pimpinan dan penghargaan mendapatkan perhatian dan ditingkatkan agar kinerja pegawai bisa tetap ditingkatkan, sehingga prestasi kerja atau kinerja individu dan organisasi meningkat. Kedua; sarana dan prasarana penunjang agar bisa lebih dilengkapi yang belum ada. Juga lingkungan agar ada kerindangan dan tanaman depan kantor sebagai pelindung dan peredam suara bising baik kendaraan maupun Manusia. Ketiga; agar pemerintah lebih memperhatikan kesejahteraan PNS terutama faktor kompensasi, bisa ditingkatkan bila bisa setara dengan yang didapatkan di BUMN atau perusahaan-perusahaan swasta; ada tunjangan cuti/hari libur, tunjangan penghasilan, tunjangan keluarga, tunjangan kesehatan, tunjangan pendidikan anak dan lain sebagainya. Agar bisa lebih terangkat kemampuan ekonominya juga status sosialnya di mata masyarakat. Yang berdampak akan kebanggaan dan rasa puas sebagai PNS.

\section{DAFTAR PUSTAKA}

Abdul Ghoffar, 2009. Perbandingan Kekuasaan Presiden Indonesiasetelah Perubahan UUD 1945 dengan Delapan Negara Maju.Karya Kencana: Yogyakarta.

Dadang Juliantoro, dkk, 2000. Strategi Tiga Kaki: dari Pintu OtonomiDaerah Mencapai Keadilan Sosial, Lapera Pustaka Utama:Yogyakarta

Djoko Prakoso, 1984. Kedudukan dan Fungsi Kepala Daerah besertaPerangkat Daerah lainnya di dalam Undang-Undang Pokok Pemerintahan Di daerah, Ghalia Indonesia: Jakarta.

Djoko Sutono, 1982. Pengantar Penelitian Hukum, UI Press: Jakarta

Faisal Abdullah, 2009. Prinsip, Konsep dan Tantangan dalam NegaraHukum, Pukap Indonesia: Makassar.

Jhon M. Echols dan Hasan Shadily, 2007. Kamus Inggris-IndonesiaCetakan Keduapuluh Sembilan, PT. Gramedia: Jakarta.

Moh. Mahfud MD, 2001. Dasar dan Hukum Ketatanegaraan Indonesia, Rineka Cipta: Jakarta.

NieematulHuda, 2005. Hukum tata Negara Indonesia, Raja Grafindo Persada: Jakarta.

Philipus M. Hadjon, 2002. Pengantar Hukum Administrasi Indonesia, Gadjah Mada University Press: Yogyakarta. 
Siagian S.P, 1996. Manajemen Sumber Daya Manusia, Bumi Aksara; Bandung.

Simamora H, 1995, Manajemen Sumber Daya Manusia, STIE YKKPN:Yogyakarta.

Undang-Undang Nomor 1 Tahun 1945 tentang Pemerintahan Daerah UndangUndang Nomor 18 tahun 1965 tentang pemerintahan daerah Undangundang Nomor 22 Tahun 1999 Undang-undang Nomor 32 Tahun 2004 Undang-Undang Dasar Negara Republik Indonesia 1945.

Undang-UndangNomor 43 Tahun 1999 Tentang Perubahan Atas UndangUndang Nomor 8 Tahun 1974 Tentang Pokok-Pokok Kepegawaian.

Peraturan Pemerintah Nomor 9 Tahun 2003 tentang Wewenang Pengangkatan, Pemindahan Dan Pemberhentian Pegawai Negeri Sipil yang telah dilakukan perubahan Yakni Peraturan Pemerintah Republik Indonesia Nomor 63 Tahun 2009. 